\title{
Signaling By Signature: The Weight of International Opinion and Ratification of Treaties by Domestic Veto Players
}

\author{
David Hugh-Jones, Karolina Milewicz ${ }^{\dagger} \&$ Hugh Ward $^{\ddagger}$
}

\begin{abstract}
The signing of international treaties is usually considered insignificant for international legal cooperation. Accordingly, International Relations theorists have paid it little attention. We show in this paper how and why treaty signature matters for the ultimate decision to ratify an international treaty. We argue that when multiple well-informed actors publicly sign an international treaty, this can provide a strong signal of issue importance to domestic veto players, and in turn may persuade them to ratify the treaty. We formalize this argument in a two-level signaling game, and test it on a data set of 126 international environmental agreements. We find that treaties are more likely to be ratified when their signatories include countries with high levels of general or issue-specific knowledge.
\end{abstract}

Keywords: ratification, signature, environmental treaties, domestic veto players, signaling.

Word count: 9,141 (plus on-line appendix).

Acknowledgements: We thank Bob Goodin, Noel Johnston, Duncan Snidal and the reviewers for valuable comments and suggestions. An earlier version of this paper was presented at the International Relations Colloquium, University of Oxford.

*University of East Anglia, School of Economics, d.hugh-jones@uea.ac.uk

${ }^{\dagger}$ University of Oxford, Department of Politics \& IR, karolina.milewicz@politics.ox.ac.uk

${ }^{\ddagger}$ University of Essex, Department of Government, hugh@essex.ac.uk 


\section{Introduction}

International treaty negotiations typically end with a treaty being signed. This is sometimes a newsworthy event where heads of state participate in a signing ceremony: for example, the Rio Summit on Environment and Development of 1992 concluded with the signing of two important United Nations (UN) Conventions - the Convention on Biological Diversity and the Framework Convention on Climate Change - by the great majority of the 172 participating governments. In most cases, however, signature is more low-key, and is likely only to be noted by policy-makers and affected interest groups in the countries concerned. But does treaty signature actually matter? Signature is not ascribed much legal importance in the process of treaty making insofar as only ratification obliges a state to comply with the treaty under international law. ${ }^{1}$ While signing might have symbolic significance, it is difficult to understand its role in the treaty process from a rational actor perspective. However, we argue that signature does matter: when a number of states simultaneously sign a treaty, this conveys important information to domestic veto players, and therefore facilitates treaty ratification.

Our argument is that signing a treaty signals to other states and domestic audiences that action on an issue is necessary. This information can persuade potential domestic veto players to ratify when they would not otherwise have done so. In choosing to sign, states take into account not only what they know about the issue, but also what other states involved in the negotiation know. We label this pooled expertise of states the weight of international opinion. In the light of the weight of international opinion, domestic veto players update their prior beliefs (cf. Igoe Walsh, 2007), and may eventually ratify a treaty that they would not have otherwise accepted - if, for example, the same policy had been proposed as

\footnotetext{
${ }^{1}$ In some cases (e.g. protocols and amendment instruments) states may accede, succeed, approve or accept a treaty without signing it. Ratification implies that an international agreement is binding (Vienna Convention on the Law of Treaties, 1969, Art. 2(1b)). Signature, on the other hand, only commits a state "to refrain from acts that would defeat the object and the purpose of the treaty" (Vienna Convention on the Law of Treaties, 1969, Art. 18a)
} 
part of domestic legislation. Just as the expertise of US Congressional committees influences the views of the median legislator (Gilligan and Krehbiel, 1990; Bendor and Meirowitz, 2004), so the pooled expertise of leaders signing a treaty may shift domestic veto players' support for ratification.

Our theoretical argument sheds new light on the importance of international law, demonstrating that international legal action may succeed when purely domestic action would fail. Like domestic legislation, ratification of a treaty requires majorities or super-majorities in legislatures, and must often pass through multiple domestic veto players - e.g. both houses of a bicameral legislature, regional assemblies in federal systems like Germany or constitutional courts as in the Czech Republic (Elkins, Ginsburg and Melton, 2010). Powerful lobby groups can also veto ratification if they think their interests would be adversely affected (Falkner, 2012). These veto players must therefore be persuaded that treaty ratification is beneficial. With such a veto player the weight of international opinion counts for more than the views of its own executive, because it sums the information held by more actors. Other things equal, domestic veto players may be persuaded to ratify an international agreement when they would have blocked domestic legislation. Seen in this light, the treaty signing stage is of considerable significance, because it may open up gridlocked domestic political agendas.

While treaty ratification and its effects have been intensively studied (e.g. Bernauer et al., 2010; Neumayer, 2002; Roberts, Parks and Vásquez, 2004; Simmons, 2009; von Stein, 2005; 2008; Vreeland, 2008), little attention has been paid to the relationship between treaty signature and ratification. Focusing on what happens after a treaty has been tabled for signature, we examine how a state's decision to ratify a treaty is affected by the pooled expertise of its signatories. Our empirical contribution is to show that the weight of international opinion represented by the expertise of states initially signing environmental treaties positively influences a state's likelihood of ratifying a treaty. 
We begin by locating our contribution in the literatures on treaty commitments and international signaling. In section 3, we develop our argument regarding the weight of international opinion. In section 4 , we test our hypothesis. In a data set of 126 international, plurilateral and regional environmental agreements (Bernauer et al., 2010), we show that treaties are more likely to be ratified when signatories included many states with technical and environmental expertise. We conclude by discussing some broad implications of international treaty signature as a signaling device.

\section{Treaties as signaling devices}

Most of the existing literature examines state-to-state signaling, in which states use treaties to signal the importance of an issue, or their own intentions, to other states. Suppose that a treaty will only be signed by states which intend to carry through their treaty commitments, because signing is too costly for untrustworthy states, for reputational or other reasons. Then a treaty signals to other states that you are trustworthy (Lipson, 1991; Fearon, 1997; Morrow, 2000). ${ }^{2}$ By signing a treaty, a state may also reveal information about its domestic audience costs of non-compliance (Espínola-Arredondo and Muñoz-García, 2011). Powerful states can use treaties to bring pressure to bear on reluctant weaker states (Roberts, Parks and Vásquez, 2004; Schneider and Urpelainen, 2013); and signing may signal that they are willing to use their power. By ratifying a treaty, states signal to other states that any domestic opposition to implementation can be overcome (Abbott and Snidal, 2000). State-to-state signaling is a plausible explanation of how treaties can facilitate cooperation between states. But we argue that it is by no means the whole story, and that it neglects interactions between the international and domestic levels that are important for securing domestic actors' consent for

\footnotetext{
${ }^{2}$ In practice the distinction between commitment and signaling may be blurred in relation to any particular institutional practice (Slantchev, 2005).
} 
international cooperation.

There is some informal discussion of signaling to domestic actors. ${ }^{3}$ In the domains of human rights (Hafner-Burton, Victor and Lupu, 2012) and climate change (Fredriksson and Gaston, 2000) leaders sign a treaty to signal to their domestic audiences their commitment to treaty-related action. Hollyer and Rosendorff, 2012 argue that some autocrats ratify human rights treaties to signal to domestic opponents their resolve to hold on to power and not to comply, thereby increasing their tenure. Treaty negotiation and ratification may generate information that helps overcome objections by domestic veto players in situations where there are knowledge asymmetries between leaders and domestic audiences (Milner, 1997). Recent empirical work on the ratification of environmental treaties shows that information revealed in the process of negotiation and ratification may change domestic actors' views about whether national action is required or desirable. Perrin and Bernauer (2010; also see Bernauer et al. (2010)) find evidence for bandwagon effects depending on the numbers of other ratifying states in the region or income group. ${ }^{4}$ Leinaweaver (2011) finds that the effect of being a signatory significantly reduces the impact of partisanship on subsequent ratification, which he takes as evidence for information transfer. Unlike us, these authors do not account for variation in states' issue expertise.

\section{Our argument: Signing as a signal}

We formalize our argument about the weight of international opinion as a signaling game between one or more executives (i.e. presidents or governments) and their domestic veto players. We contrast the treaty ratification process with the alternative of passing domestic legislation. Formal proofs are in Appendix A: here we

\footnotetext{
${ }^{3}$ Using a signaling game, Chapman (2007) models how the actions of pivotal members of the UN Security Council inform domestic politics.

${ }^{4}$ Our model could be extended to demonstrate how both signing and ratification disclose information through time.
} 
simply provide our theoretical assumptions and results. We highlight why international action may succeed where purely domestic action would be vetoed; and clarify when signing is (and is not) informative to veto players.

To recap, we argue that political executives must persuade domestic veto players of the importance of policy action on an issue, whether by participating in international negotiations or by tabling purely domestic legislation. While introducing legislation signals that an executive considers an issue important, that alone may not persuade veto players, who may have different preferences and/or prior beliefs, and who may view the executive as biased and/or cognitively fallible. However, if executives from many countries simultaneously sign a treaty, then this can potentially provide a stronger signal: not just one, but many actors believe that action is important. This stronger signal can persuade domestic vetoes to support policy change.

First we assume that policy is complex and political actors' cognitive resources are limited: therefore, there is uncertainty about the effect of policy action. In particular, we focus on a single binary policy which is aimed at addressing an issue; with some probability, the policy will be beneficial to states that introduce it; otherwise, the policy will bring no benefit but only costs. Policy makers are uncertain what the true state of affairs is. We make no distinction between the seriousness of the issue and the efficacy of the policy: policy makers may either be uncertain whether the underlying issue is serious, or whether the policy is appropriate to address an issue which is known to be serious.

Second we assume that different actors experience different net costs of introducing a policy. For example, "greener" politicians will weigh the regulatory costs and ecological benefits of environmental regulation differently than political actors with ties to a business constituency. Thus, each executive, and each domestic veto player, has a different cost for introducing legislation and an expected payoff for acting. These costs can reflect not only objective beliefs about policy, 
but also political preferences and ideological commitments, such as preferences for international cooperation or skepticism towards human-induced climate change.

Domestic veto players often have less policy expertise than executives. Legislatures face a collective action problem in acquiring issue expertise (Gilligan and Krehbiel, 1990), executives, on the other hand, have access to policy experts. State agencies such as the US Environmental Protection Agency are legally obliged to provide information and expertise to executives, whereas legislators' access to this know-how is more mediated. On highly technical issues such as the environment, this is likely to result in information asymmetries, although some legislators may specialize in the issue. Our third simplifying assumption is that only executives receive a private signal about the policy, while domestic veto players must rely on their prior. Again, what matters is not our simplifying assumption that vetoes do not get a signal, but the weaker condition that they do not already know all the information known by all executives worldwide, and can therefore be persuaded by that information and by actions which signal it.

We also assume that executives from different countries have different levels of expertise. Executives from developed countries with high levels of scientific expertise will be more informed about the policy's effects than those from countries with a weak scientific base; countries deeply affected by a particular issue, such as fisheries policy for countries with a large fishing industry, will have more expert executives than unaffected countries; and countries with long experience of environmental treaty implementation will have more knowledge and expertise available than countries with less experience.

Our model explicitly assumes away any policy interdependencies across states: the benefit of the policy in a given country is independent of whether other countries introduce the policy. To be clear, we believe that treaty ratification typically does involve international externalities (Axelrod and Keohane, 1985). However, our assumption allows us to show that our signaling rationale for treaty signature 
exists even in the absence of other, more substantive policy reasons for coordinated action, such as externalities. Below, we argue that relaxing the assumption of independent policy benefits would further strengthen the signaling rationale for treaty signature.

Lastly, our game form embodies assumptions about the politics of the treaty process. After a state's executive (or her diplomatic representatives) has signed, the treaty is submitted for ratification. Then each domestic veto players decides whether to allow ratification of the treaty having observed which other executives have signed it. Since any veto player (by definition) can block action, it is a country's most skeptical veto player that must be convinced. For expositional brevity we sometimes call this player "the legislature", but nothing hangs on this. The domestic legislation and international treaty routes involve different knowledge conditions. The treaty route involves a public signing event in which many countries participate. This makes countries' commitment visible to domestic veto players, via e.g. reports in the media. For example, climate change agreements have received considerable media attention (Schmidt, Ivanova and Schäfer, 2013). By contrast, if domestic legislation is introduced, we assume that domestic veto players do not observe action in other countries - a strong assumption, but one which captures the direction of the difference we expect.

Note that both signing a treaty and introducing domestic legislation are more than just "cheap talk". Both actions have real effects, in that they can lead to legislation being implemented. A country's executive will only take either action if it genuinely believes that legislation is necessary. ${ }^{5}$

\footnotetext{
${ }^{5}$ Technically, introducing legislation that you believe to be harmful is a weakly dominated action.
} 
Under the above assumptions, an executive which introduces domestic legislation will pass it only if its own expertise is enough to convince the country's most skeptical veto. An executive with a very strong preference for action - strong enough that it always prefers legislation to pass, whether or not its private information indicates that the policy is appropriate - will not be able to credibly signal information to domestic audiences. Even a more neutral executive may simply lack enough expertise to persuade domestic vetoes that the policy is appropriate. However, if executives from many countries sign a treaty, then this can generate a more powerful signal that the treaty's policy is the right response. The signal does not necessarily incorporate the expertise of each and every signing country, since in equilibrium, some executives may free-ride on the expertise of others a phenomenon known in domestic politics as the Swing Voter's curse (Feddersen and Pesendorfer, 1996). However, we show computationally in Appendix B that in general the strength of the signal is highly correlated with the sum of the expertise of all signatories. This result leads us to our main hypothesis.

The likelihood of a legislature ratifying a treaty increases with the summed expertise of the signatory countries.

Next, consider the effect of an increase in the number of domestic veto players. Recall that the relevant actor is the most skeptical veto player in a country. Suppose that the number of veto players in this country increases by one. Clearly the signal strength required to persuade the most skeptical veto can only stay the same or increase. How will this change the marginal effect of an increase in pooled expertise? In Appendix B we show that an increase in the number of veto players can either increase or decrease this marginal effect. We therefore test empirically for the interaction between expertise and number of veto players but are agnostic about the direction of result. 


\section{Relaxing the assumptions}

2 We now ask what happens when we relax our assumptions. In the basic model, domestic veto players have no private information about the policy. This is unre4 alistic. If veto players receive their own private signal about the policy, then the 5 effects are ambiguous. A veto player who is wholly uninformed about the issue and who perceives high costs of action might never ratify a treaty, even one signed by countries with great policy expertise. The same veto player, after having received its own reasonably accurate signal that the policy is beneficial, might be persuaded to sign. However, as a domestic veto player gets more accurate information about the issue, it eventually ceases to rely on information from others. In the limit, a domestic veto player who knows for sure whether the policy is appropriate will accept legislation only if it is, whether the domestic legislation or the treaty route is taken, and irrespective of the expertise of other parties. At this point our argument would no longer apply. Our theory requires, and we maintain, that in many policy areas, domestic veto players are less well informed than this. As an example, consider a domestic veto whose signal is exactly as accurate as the executive's, and who is a priori skeptical about the policy, in the sense that prior to receiving any signals, she would not prefer the policy to be implemented. The executive alone can never persuade this veto to act against her own signal. For, if the veto receives a negative signal about the policy, then a positive signal from the executive simply brings her back to her skeptical prior. Only the treaty route may provide enough information to override such a veto's negative signal.

In our model, countries benefit from the policy (if it is appropriate) irrespective of whether other countries take action. In reality, treaties often serve to coordinate action on issues where there are externalities. Transboundary pollution can be dealt with better if many countries simultaneously commit to environmental measures. Indeed, the literature treats this coordination as a central reason for the existence of international treaties (and we agree). To consider this aspect, sup- 
pose that each country's benefit from introducing an appropriate policy increases with the number of other countries that do so. Now, there will be two benefits to taking the treaty route, compared to introducing legislation on a country-bycountry basis. First, the signal of expertise will be stronger, as before. Second, this stronger signal will lead each country to expect more other countries to ratify the treaty. This will encourage the country to ratify, which in turn will encourage other countries, and so on. Thus, with positive externalities, the information benefits of treaties, and the marginal effect of signatories' expertise, are likely to increase.

The model assumes that treaty signature is costless, and its only effect is to allow the country's legislature to ratify the treaty. Both these assumptions are challengeable. Failure to pass a treaty, after a highly-publicized signing process, can cause audience costs for executives, both with the international community and among domestic publics for whom the issue is salient. On the other hand, legislatures may be able to introduce domestic legislation irrespective of the treaty's status, and countries may accede to an existing treaty without having been a signatory. These facts push in different directions. If acceding to a treaty is as easy as ratifying, then signing a treaty is pure "cheap talk" and can convey nothing. On the other hand, audience costs of signing a treaty may serve to demonstrate the executive's belief that the policy is appropriate, in line with a costly signaling logic. Then, treaty signature may convey useful information even if it does not affect the legislature's ability to accede or ratify.

Lastly, we assume that the content of the treaty is fixed at the start of the game. In fact, we know that treaty content is negotiated with one eye on domestic veto players (Putnam, 1988; Mo, 1995; Brown and Urpelainen, 2015). Moreover, domestic vetoes may pre-empt the treaty from reaching the international agenda at all, if it takes certain specific forms to which they are opposed (Barrett, 2003: 148). This complicates the analysis, since now not only the set of signing executives, but 
also the content of the treaty itself, might convey information to domestic vetoes. One way of thinking about this is that in the existing setup, executives choose between signing the treaty, and signing no treaty. A more complex model would allow a range of possible treaties, taking weaker or stronger measures to deal with the underlying issue, with executives negotiating to find a treaty that all are willing to sign (including a possible "null" treaty that takes no meaningful action). Legislatures would then observe the treaty signature and choose whether to ratify.

We believe that in such a more complex model, our basic insight would still hold. So long as executives who desire a stronger policy (conditional on their private information) will want to sign stronger treaties; the strength of the treaty signed will be positively correlated with executives' private information. Legislatures will in turn be more influenced by this information if it comes from executives with issue expertise, i.e. accurate signals. Thus, allowing treaty content to be negotiated may generate further predictions, but should not reverse our hypothesis.

\section{Empirical analysis}

\subsection{Outcome variable and estimation technique}

To test the effects of signing on the likelihood of treaty ratification, we use environmental treaty ratification data from Bernauer et al. (2010). ${ }^{6}$ The data set includes 255 multilateral, plurilateral and regional treaties (covering conventions, protocols and amendments) and spans the period 1952 to 2000.

Because our argument focuses on the relationship between treaty signature and ratification, we study only treaties that require two separate approval steps, signature and ratification, and exclude treaties which lack an explicit signature step - protocols and amendments in particular. This leaves us with 126 environmental treaties which require both signature and ratification.

\footnotetext{
${ }^{6}$ We thank these authors for making their data available to us.
} 
Finally, while the data set includes environmental treaties, some of the treaties are not narrowly environmental in focus, but are also concerned with other issues (e.g. the Aarhus Convention touches upon human rights). This does not present a problem for us as our argument is not restricted to any substantive domain. However, we account for treaty heterogeneity by stratifying our models for issue areas of treaties (see Robustness checks).

To study ratification data, we use event history analysis. Event history analysis is particularly suited to study the change in status from non-ratification to ratification of a given treaty. It not only considers which states ratify a treaty, but also takes into account the time lapse until ratification occurs. Moreover, event history analysis accounts for the fact that observed data is incomplete. ${ }^{7}$ Time to ratification cannot be observed in full and remains unknown for some states, due to censoring and truncation of data (Klein and Moeschberger, 2003). We are faced with fixed and random right-censoring as well as left-truncation. Fixed rightcensoring refers to states that had not ratified a particular treaty at the end of the analysis in December 2000; random right-censoring refers to states that ceased to exist before the end of the analysis in 2000, e.g. Czechoslovakia (state termination in 1992). Left-truncation exists for successor states (e.g. of Yugoslavia and the Soviet Union), since these states enter late into the database.

Another important feature of the event history method is its applicability to data with "multiple events per subject" (Therneau and Grambsch, 2000). We need to allow for the possibility that each state can ratify any number of our set of treaties in any given year the treaty was open for ratification. In order to account for this, we organized our ratification data as count data following Andersen and Gill (AG) (1982). The data takes the form of country-treaty-year, with years being

\footnotetext{
${ }^{7}$ Bernauer et al. (2010) results are estimated with a time-series-cross sectional approach for annual ratification data (Beck, Katz and Tucker, 1998) controlling for the baseline hazard with polynomials in time (Carter and Signorino, 2010); they check for robustness by using event history methods. Perrin and Bernauer (2010) use similar method to Bernauer et al. (2010). Roberts, Parks and Vásquez (2004) is a cross-sectional study. Like us, Fredriksson and Gaston (2000) use the Cox proportional hazards model.
} 
formulated as intervals indicating the start and end of the count. The year count ends with the occurrence of an event for any given country and treaty (represented 3 by "status" equaling 1), resulting in a varying length of the count for any country4 treaty. $^{8}$ Table 1 illustrates the count structure of our ratification data in more 5 detail, providing also examples for right-censoring and left-truncation.

\begin{tabular}{lcccccc}
\hline Country & Treaty & Year & Start & Stop & Status & Interval \\
\hline Federal Republic of Germany & CITES & 1974 & 1973 & 1974 & 0 & $(0,1+]$ \\
Federal Republic of Germany & CITES & 1974 & 1974 & 1975 & 0 & $(1,2+]$ \\
Federal Republic of Germany & CITES & 1974 & 1975 & 1976 & 1 & $(2,3]$ \\
German Democratic Republic & CITES & 1974 & 1983 & 1984 & 0 & $(10,11+]$ \\
German Democratic Republic & CITES & 1974 & 1984 & 1985 & 0 & $(11,12+]$ \\
German Democratic Republic & CITES & 1974 & 1985 & 1986 & 0 & $(12,13+]$ \\
German Democratic Republic & CITES & 1974 & 1986 & 1987 & 0 & $(13,14+]$ \\
German Democratic Republic & CITES & 1974 & 1987 & 1988 & 0 & $(14,15+]$ \\
German Democratic Republic & CITES & 1974 & 1988 & 1989 & 0 & $(15,16+]$ \\
German Democratic Republic & CITES & 1974 & 1989 & 1990 & 0 & $(16,17+]$ \\
Croatia & CITES & 1974 & 1991 & 1992 & 0 & $(18,19+]$ \\
Croatia & CITES & 1974 & 1992 & 1993 & 0 & $(19,20+]$ \\
Croatia & CITES & 1974 & 1993 & 1994 & 0 & $(20,21+]$ \\
Croatia & CITES & 1974 & 1994 & 1995 & 0 & $(21,22+]$ \\
Croatia & CITES & 1974 & 1995 & 1996 & 0 & $(22,23+]$ \\
Croatia & CITES & 1974 & 1996 & 1997 & 0 & $(23,24+]$ \\
Croatia & CITES & 1974 & 1997 & 1998 & 0 & $(24,25+]$ \\
Croatia & CITES & 1974 & 1998 & 1999 & 0 & $(25,26+]$ \\
Croatia & CITES & 1974 & 1999 & 2000 & 0 & $(26,27+]$ \\
\hline & & & & & & \\
\hline
\end{tabular}

Table 1: Excerpt of the count data.

Notes: Federal Republic of Germany is an untruncated and uncensored data example; German Democratic Republic is random right-censored (ceased to exist in 1989); and Croatia is lefttruncated (exists since 1991) and fixed right-censored (no ratification at the end of period of analysis).

Treaty CITES - Convention on International Trade in Endangered Species of Wild Fauna and Flora.

Year Year in which treaty opened for ratification.

Start Begin of the year count.

Stop End of the year count.

Status 1: ratification; 0: no ratification.

Interval The interval (start, stop] is open on the left and closed on the right; it indicates begin and end of the count (based on the year 1974 when treaty opened for ratification) for each treaty within a country. + indicates the incomplete nature of the data (no event or right-censoring).

\footnotetext{
${ }^{8}$ The count data is set up at annual intervals to accommodate time-varying covariates.
} 


\footnotetext{
${ }^{9}$ Since we excluded protocols and amendments which are contingent on ratification of an earlier treaty from our data set, we do not compromise this conditional independence assumption.

${ }^{10}$ The clustering function is used in the context of survival models to account for intra-group correlations. It is thus similar to fixed effects, but does not yield additional fixed effects parameters.

${ }^{11}$ The likelihood is approximated by the Efron method which is particularly accurate in dealing with tied data.

${ }^{12}$ The Cox model is characterized by an unspecified baseline hazard function. The unspecified baseline allows the hazard function to vary with time, and thus is able to capture potential time trends.

${ }^{13}$ The hazard ratio must be independent of time. Results based on scaled Schoenfeld residuals indicate that this proportional hazards assumption is satisfied by all covariates. Model checks and data diagnostics are available from the authors on request.
} 
they did so (based on CIESIN, 2006; cross referenced with Mitchell and Hensel, 2007). Our formal model assumes a coordinated signing event. In practice such an event does not always happen and signatures may continue to accumulate for some time. However, signing is usually bunched in the first year of the life of a treaty; and typically treaties are only open for signature for a limited period - often a year. Over the treaties analyzed here, around $80 \%$ of the states that signed did so in the first year after opening for adoption. We therefore define states that sign within the first year as "first signers" of a treaty, for which the binary variable FIRST_SIGN is 1 and 0 otherwise.

Next, we need to measure our main explanatory variable - states' knowledge of environmental issues, which is a challenge. We develop four alternative measures. The most direct measure of a country's environmental expertise is its research output in this discipline. SCImago (2015) provides several measures of countries' research output categorized by Scopus subject areas. We started with the number of documents published by each country in each year categorized as environmental science. ${ }^{14}$ For each treaty we summed across the group of first signers the number of documents reported by SCImago for those countries in the first year of signing. This variable is denoted by DOCS_I_SIGN. It captures the summed environmental expertise of first signers, on the assumption that contacts between the research community and the government are well-developed and executives listen to advice. Although the variable provides a good measure of environmental-science output, unfortunately its temporal coverage is quite limited, starting in 1996.

For each treaty we summed across the group of first signers the number of patents lodged by each country in the year of first signing (World Bank, 2015). ${ }^{15}$ This patent variable is denoted by PATENT_I_SIGN and is standardized to avoid

\footnotetext{
${ }^{14}$ We considered weighting for citations, but such weightings are somewhat contentious and it made little difference to DOCS_I_SIGN.

${ }^{15}$ Where data on patents was missing for some country years we linearly interpolated. Some poorer and smaller states never report. In all likelihood they produce very few patentable ideas; so we treated such cases as zeros.
} 
small coefficients. The bivariate correlation between PATENT_I_SIGN and DOCS_I_SIGN is .915. This suggests that countries' expertise in environmental science is highly correlated with their general expertise in the natural sciences and technology. Because the temporal coverage of PATENT_I_SIGN is much greater, allowing us to make full-use of the ratification data going back to 1961, we report results using PATENT_I_SIGN rather than DOCS_I_SIGN.

Another, more informal, type of expertise relevant for regulating and adapting to environmental problems is based on experience and tacit knowledge. Countries with long experience in implementing key environmental treaties are likely to be in a better position to judge impacts. Our second proxy EXPERIENCE_I_SIGN reflects this aspect of expertise, and captures the collective experience of first signers with major multilateral environmental treaties. The variable is measured as the standardized number of years a country has accumulated since ratifying nine key environmental treaties as identified in the International Trade and Agricultural Policy (IATP) treaty database (IATP, 2005). ${ }^{16}$ As before, the variable is then summed over the group of first signers for a given treaty.

Finally, we also test for issue-specific knowledge focusing on a narrower domain of environmental regulation, marine treaties. Our proxy measure for issuespecific expertise, MARINE_I_SIGN, is the ratio of coastline to land area (CIA, 2013), summed over first signers. The idea is that maritime states have a greater incentive to gather knowledge on maritime issues. While past treaty experience measured by EXPERIENCE_I_SIGN could be correlated with omitted variables, such as an early signer's concern for the environment or central position in relevant international networks (Ward, 2006), MARINE_I_SIGN, by contrast, is likely to be exogenous to most forms of international power.

\footnotetext{
${ }^{16}$ These are: the UN Convention on the Law of the Sea, Montreal Protocol, the Basel Convention, the UN Framework Convention on Climate Change, Kyoto Protocol, the Convention on Biological Diversity, Cartagena Protocol, the UN Convention to Combat Desertification and the Rotterdam Convention. The Stockholm Convention and the International Treaty on Plant Genetic Resources for Food and Agriculture are also included in the IATP database but are not part of our treaty sample.
} 
We also control in our models for obvious confounders. Because the number 2 of patents might just capture the general international influence of wealthy coun3 tries, not something specific about their knowledgeability, we constructed a control 4 variable WEALTH_I_SIGN reflecting the wealth of first signers. Similarly, because 5 countries that produce many patents tend to be large and powerful, a country's 6 number of patents might be associated with its power position in the international 7 system. To control for this correlation we constructed POWER_I_SIGN. Both vari8 ables are constructed in the same way as PATENT_I_SIGN. WEALTH_I_SIGN gives 9 the summed GDP per capita of countries belonging to the group of first signato10 ries in the year of signing (World Bank, 2015). POWER_I_SIGN gives first signers' summed military capability scores (the Composite Index of National Capability 12 CINC) from the Correlates of War Project (Singer, Bremer and Stuckey, 1972). 13 As shown in Table 2, the correlations between these three variables are relatively 14 high. 


\begin{tabular}{|c|c|c|c|c|c|c|c|c|}
\hline & & FIRST_SIGN & DOCS_I_SIGN & PATENT_I_SIGN & EXPERIENCE_I_SIGN & MARINE_I_SIGN & WEALTH_I_SIGN & POWER_I_SIGN \\
\hline \multirow{7}{*}{$\overrightarrow{0}$} & FIRST_SIGN & 1.000 & 0.430 & 0.515 & 0.536 & -0.100 & 0.539 & 0.504 \\
\hline & DOCS_I_SIGN & 0.430 & 1.000 & 0.917 & 0.763 & -0.071 & 0.846 & 0.933 \\
\hline & PATENT_I_SIGN & 0.515 & 0.917 & 1.000 & 0.829 & -0.129 & 0.935 & 0.964 \\
\hline & EXPERIENCE_I_SIGN & 0.536 & 0.763 & 0.829 & 1.000 & -0.161 & 0.944 & 0.787 \\
\hline & MARINE_I_SIGN & -0.100 & -0.071 & -0.129 & -0.161 & 1.000 & -0.170 & -0.113 \\
\hline & WEALTH_I_SIGN & 0.539 & 0.846 & 0.935 & 0.944 & -0.170 & 1.000 & 0.897 \\
\hline & POWER_I_SIGN & 0.504 & 0.933 & 0.964 & 0.787 & -0.113 & 0.897 & 1.000 \\
\hline
\end{tabular}

Table 2: Correlation matrix. 
In models testing for issue specific knowledge by MARINE_I_SIGN, we control for a state's own coastline to land area ratio, R_COAST_LAND (CIA, 2013). We also include a number of other relevant factors largely following Bernauer et al. (2010). We include international influences on treaty ratification, measured as the number of international organizations (IO_MEMBERSHIP) a state belongs to (cf. Neumayer, 2002). Because a state may be more likely to ratify when other states have already done so (Simmons, 2009), we include the number of other states that have already ratified, both globally (THRESHOLD); and in the state's region (LAGPEREGION). We control for trade intensity - the sum of exports and imports divided by gross national product (OPEN) - as it might affect ratification negatively due to the possible effects of environmental provisions on international competitiveness. We also include real income per capita to baseline year 2005 US\$ (RGDPL), calculated using the Lasperes method from Penn World Table, and its square (RGDPLSQ) (Heston, Summers and Aten, 2009). ${ }^{17}$ To capture whether a state is more likely to ratify as its environment deteriorates, we use sulphur dioxide emissions per capita, logged (LNSO2PC) as a general indicator for environmental quality (Bernauer et al., 2010). We test for the effects of democracy by mean scores on Freedom House's political and civil rights index (MEANPC) (Freedom House, 2015), ${ }^{18}$ and the size of states' economy (GDPL) on ratification (Heston, Summers and Aten, 2009). Descriptive statistics for all explanatory variables are presented in Table 3.

\footnotetext{
${ }^{17}$ Both variables are standardized to avoid small coefficients.

${ }^{18}$ In Appendix C, Table 7 we also report results based on POLITY2 (Marshall, Gurr and Jaggers, 2014). While MEANPC is only available from 1972 onwards for 186 states, POLITY2 has temporal coverage back to 1950 but only for 157 states. Results based on POLITY2 are however similar to our primary findings.
} 


\begin{tabular}{lccccc}
\hline & Min & Max & Mean & Std. Deviation & Observations \\
\hline DOCS_I_SIGN & 0.00 & 40850 & 13320 & 13210.1 & 9172 \\
PATENT___SIGN & -0.79 & 5.44 & 0.11 & 1.14 & 266642 \\
EXPERIENCE_I_SIGN & -0.19 & 13.72 & 0.02 & 1.05 & 342668 \\
MARINE_I_SIGN & 0.00 & 15.60 & 0.90 & 1.86 & 161886 \\
(based on subsample) & & & & & \\
\hline Controls & & & & & \\
FIRST_SIGN & 0.00 & 1.00 & 0.07 & 0.25 & 342668 \\
WEALTH_I_SIGN & -0.64 & 6.85 & 0.37 & 1.21 & 266642 \\
POWER_I_SIGN & -0.72 & 4.13 & 0.39 & 1.14 & 342668 \\
R_COAST_LAND & 0.00 & 8.71 & 0.11 & 0.58 & 157595 \\
(based On subsample) & & & & & \\
IO_MEMBERSHIP & 1.00 & 134.00 & 50.70 & 20.99 & 308238 \\
THRESHOLD & 0.00 & 180.00 & 18.62 & 23.39 & 342668 \\
LAGPERCREGION & 0.00 & 97.87 & 7.13 & 14.40 & 342668 \\
OPEN & -0.77 & 10.31 & 0.00 & 1.01 & 317866 \\
RGDPL & -0.76 & 6.78 & 0.00 & 1.01 & 313388 \\
RGDPLSQ & -0.37 & 12.83 & 0.00 & 1.01 & 313388 \\
LNSO2PC & -4.34 & 9.58 & 3.65 & 2.16 & 300197 \\
MEANPC & 1.00 & 7.00 & 3.97 & 2.04 & 307720 \\
POLITY2 & -10.00 & 10.00 & -0.06 & 7.38 & 291960 \\
GDPL & -0.26 & 15.67 & 0.00 & 0.99 & 292461 \\
\hline
\end{tabular}

Table 3: Descriptive statistics.

\subsection{Results}

2 In Table 4 we present four models. All models test our hypothesis regarding 3 the effect of signatory countries' pooled expertise on the likelihood of a state 4 ratifying a treaty, using our alternative measures of expertise. In all models we 5 include the controls introduced above. Given that the controls do not show any unexpected directions of effects, we focus here on the interpretation of our key explanatory variables - PATENT_I_SIGN, EXPERIENCE_I_SIGN and MARINE_I_SIGN.

8 In Appendix C, Table 6 we also present equivalent models without the controls 9 (except for FIRST_SIGN, and R_COAST_LAND in models including MARINE_I_SIGN). Overall, the coefficient values and significance levels were reasonably stable across the reduced and full variants of all our models. ${ }^{19}$

\footnotetext{
${ }^{19}$ To check whether the effect of pooled expertise is conditioned by the importance of countries at the negotiation stage, we interacted our main variables with the number of countries' signatures and also controlled our models for the number of countries' signatures. However, the inclusion of both terms did not make any substantive difference to our results.
} 


\begin{tabular}{|c|c|c|c|c|}
\hline & $\begin{array}{c}\text { Model 1 } \\
\exp (\text { coef }) \\
(p)\end{array}$ & $\begin{array}{c}\text { Model 2 } \\
\exp (\text { coef }) \\
(p)\end{array}$ & $\begin{array}{c}\text { Model } 3 \\
\exp (\text { coef }) \\
(p)\end{array}$ & $\begin{array}{c}\text { Model } 4 \\
\exp (\text { coef }) \\
(p)\end{array}$ \\
\hline \multicolumn{5}{|l|}{ Pooled expertise } \\
\hline PATENT_I_SIGN & $\begin{array}{c}1.369 \\
\left(0.000^{* * *}\right)\end{array}$ & & & $\begin{array}{c}1.147 \\
\left(0.000^{* * *}\right)\end{array}$ \\
\hline EXPERIENCE_I_SIGN & & $\begin{array}{c}1.262 \\
(0.000 * * *)\end{array}$ & & \\
\hline MARINE_I_SIGN & & & $\begin{array}{c}1.068 \\
\left(0.000^{* * *}\right) \\
\end{array}$ & \\
\hline \multicolumn{5}{|l|}{ Controls } \\
\hline FIRST_SIGN & $\begin{array}{c}4.659 \\
\left(0.000^{* * *}\right)\end{array}$ & $\begin{array}{c}4.937 \\
\left(0.000^{* * *}\right)\end{array}$ & $\begin{array}{c}6.406 \\
\left(0.000^{* * *}\right)\end{array}$ & $\begin{array}{c}4.037 \\
\left(0.000^{* * *}\right)\end{array}$ \\
\hline WEALTH_I_SIGN & & & & $\begin{array}{c}1.449 \\
\left(0.000^{* * *}\right)\end{array}$ \\
\hline POWER_I_SIGN & & & & $\begin{array}{c}0.755 \\
\left(0.000^{* * *}\right)\end{array}$ \\
\hline R_COAST_LAND & & & $\begin{array}{c}3.408 \\
\left(0.026^{*}\right)\end{array}$ & \\
\hline IO_MEMBERSHIP & $\begin{array}{c}1.005 \\
(0.116)\end{array}$ & $\begin{array}{c}1.004 \\
(0.188)\end{array}$ & $\begin{array}{c}1.007 \\
\left(0.041^{*}\right)\end{array}$ & $\begin{array}{c}1.006 \\
\left(0.030^{*}\right)\end{array}$ \\
\hline THRESHOLD & $\begin{array}{c}1.005 \\
\left(0.001^{* * *}\right)\end{array}$ & $\begin{array}{c}1.011 \\
\left(0.000^{* * *}\right)\end{array}$ & $\begin{array}{c}1.015 \\
\left(0.000^{* * *}\right)\end{array}$ & $\begin{array}{c}1.006 \\
\left(0.000^{* * *}\right)\end{array}$ \\
\hline LAGPERCREGION & $\begin{array}{c}1.019 \\
\left(0.000^{* * *}\right)\end{array}$ & $\begin{array}{c}1.020 \\
\left(0.000^{* * *}\right)\end{array}$ & $\begin{array}{c}1.017 \\
\left(0.000^{* * *}\right)\end{array}$ & $\begin{array}{c}1.020 \\
\left(0.000^{* * *}\right)\end{array}$ \\
\hline OPEN & $\begin{array}{c}0.963 \\
(0.402)\end{array}$ & $\begin{array}{c}0.968 \\
(0.410)\end{array}$ & $\begin{array}{c}0.978 \\
(0.680)\end{array}$ & $\begin{array}{c}0.950 \\
(0.281)\end{array}$ \\
\hline RGDPL & $\begin{array}{c}1.158 \\
(0.234)\end{array}$ & $\begin{array}{c}1.128 \\
(0.337)\end{array}$ & $\begin{array}{c}1.247 \\
(0.222)\end{array}$ & $\begin{array}{c}1.107 \\
(0.408)\end{array}$ \\
\hline RGDPLSQ & $\begin{array}{c}0.922 \\
(0.452)\end{array}$ & $\begin{array}{c}0.936 \\
(0.542)\end{array}$ & $\begin{array}{c}0.897 \\
(0.518)\end{array}$ & $\begin{array}{c}0.964 \\
(0.724)\end{array}$ \\
\hline LNSO2PC & $\begin{array}{c}1.095 \\
(0.000 * * *)\end{array}$ & $\begin{array}{c}1.101 \\
\left(0.000^{* * *}\right)\end{array}$ & $\begin{array}{c}1.076 \\
\left(0.018^{*}\right)\end{array}$ & $\begin{array}{c}1.089 \\
\left(0.000^{* * *}\right)\end{array}$ \\
\hline MEANPC & $\begin{array}{c}1.116 \\
\left(0.000^{* * *}\right)\end{array}$ & $\begin{array}{c}1.111 \\
\left(0.000^{* * *}\right)\end{array}$ & $\begin{array}{c}0.990 \\
(0.772)\end{array}$ & $\begin{array}{c}1.120 \\
\left(0.000^{* * *}\right)\end{array}$ \\
\hline GDPL & $\begin{array}{c}0.959 \\
\left(0.031^{*}\right)\end{array}$ & $\begin{array}{c}0.968 \\
(0.073) \\
\end{array}$ & $\begin{array}{c}1.065 \\
\left(0.004^{* *}\right)\end{array}$ & $\begin{array}{c}0.962 \\
(0.051) \\
\end{array}$ \\
\hline LRT & $\begin{array}{c}6002 \\
(0)\end{array}$ & $\begin{array}{c}6330 \\
(0)\end{array}$ & $\begin{array}{c}1591 \\
(0)\end{array}$ & $\begin{array}{c}6399 \\
(0)\end{array}$ \\
\hline $\begin{array}{l}(p) \\
\text { Wald test }\end{array}$ & $\begin{array}{c}(0) \\
4373\end{array}$ & $\begin{array}{c}(0) \\
4341\end{array}$ & $\begin{array}{c}(0) \\
1179\end{array}$ & $\begin{array}{c}(0) \\
4497\end{array}$ \\
\hline$(p)$ & $(0)$ & $(0)$ & $(0)$ & $(0)$ \\
\hline $\begin{array}{l}\text { Robust (score) logrank test } \\
(p)\end{array}$ & $\begin{array}{c}141.1 \\
(0)\end{array}$ & $\begin{array}{c}140.8 \\
(0)\end{array}$ & $\begin{array}{c}112.1 \\
(0)\end{array}$ & $\begin{array}{c}141.4 \\
(0)\end{array}$ \\
\hline No. Observations & 205384 & 250347 & 122285 & 205384 \\
\hline No. Events & 3002 & 3124 & 858 & 3002 \\
\hline No. States & 157 & 157 & 156 & 157 \\
\hline Period & $1972-2000$ & $1972-2000$ & $1972-2000$ & $1972-2000$ \\
\hline
\end{tabular}

Table 4: Cox proportional hazards regression models for treaty ratification.

Notes: Each cell entry $[\exp (\operatorname{coef})]$ is the exponential of the coefficient which is the hazard ratio (HR). The likelihood ratio test assumes independence of observations within a cluster (country); the Wald and robust score tests do not. ${ }^{* * *} p|z|=<.001,{ }^{* *} p|z|=<.01,{ }^{*} p|z|=<.05$. 
Model 1 includes PATENT_I_SIGN. In this model the hazard ratio for PATENT_I_SIGN is greater than one and significantly different from one at the .001 level. (A hazard ratio of one indicates that a variable has no effect on treaty ratification. A ratio of more than one indicates that the variable increases the likelihood of ratification.) Increasing the pooled expertise of first signers by one standard deviation increases the likelihood of ratifying a treaty by $37 \% .{ }^{20}$ This supports our hypothesis: the weight of international opinion among the group of first signers increases the propensity to ratify.

Model 2 uses the collective experience measure EXPERIENCE_I_SIGN. The collective experience of first signers with key multilateral environmental treaties has a substantial effect on other states' ratification likelihood (an increase by one standard deviation results in a $26 \%$ increase of the ratification likelihood); this effect is statistically significant at a .001 level.

In model 3, we test the effect of issue-specific knowledge with MARINE_I_SIGN. Though the treaties we deal with cover quite diverse environmental issues, around $50 \%$ of them concern maritime issues and fishing. States with extensive coastlines are likely to have more knowledge and expertise on these issues than predominantly landlocked states. We fit model 3 for a subsample of marine and fishing treaties. We include MARINE_I_SIGN (the sum of signatories' marine-related expertise, as proxied by their coast-land ratio), and, in addition to the previous controls, a measure for a state's own coastline to land area ratio, R_COAST_LAND. For both variables we found significant and positive effects, although the effect for MARINE_I_SIGN is statistically stronger than for R_COAST_LAND (which is statistically significant only at a .05 level). Thus, when it comes to issue-specific knowledge there is also evidence for the pooled expertise effect.

Finally, in model 4 we also tested whether the effect of pooled expertise measured by PATENT_I_SIGN holds against the inclusion of measures reflecting wealth

\footnotetext{
${ }^{20} \mathrm{An}$ equivalent model fit without FIRST_SIGN results in an even stronger effect for PATENT_I_SIGN (see Appendix C, Table 7).
} 


\section{${ }_{4} 4.4$ Robustness checks} show in Appendix C.

(WEALTH_I_SIGN) and the power position of first signers (POWER_I_SIGN). Again, we find a significant and positive effect for pooled expertise increasing the ratification likelihood by $15 \%$ (given a one standard deviation increases in the variable). ${ }^{21}$

To confirm our results regarding the effect of signatories' expertise on ratification, we conducted several robustness checks and fitted numerous models, which we

First, because our modeling framework involving multiple events is quite complex, we ran bootstrap simulations as an additional cross-check for Model 1 from Table 4, based on sampling with replacement. In each of the 199 runs we fitted the model to a random sample of treaties from the original data. In order to test whether the variables have a significant effect, we constructed empirical $95 \%$ confidence intervals of the parameter estimates from the posterior distribution. The simulation results (Appendix C, Figure 1) confirm that our key variables PATENT_I_SIGN from Model 1 has a significant and positive effect on the likelihood of ratification ( 0 is not within the confidence interval).

Second, the Cox proportional hazards models in Table 4 assume one baseline hazard for all treaties, which however address different issues in environmental regulation. Thus, we stratified our models on a categorical ISSUES variable allowing the baseline hazard to vary across treaties. This variable differentiates between ten areas of environmental regulation: general/governance; atmosphere; hazardous substances; marine environment; nature conservation and terrestrial living resources; energy; nuclear safety; marine living resources; freshwater sources; conflict and disasters. The stratified models closely resemble those in Table 4,

\footnotetext{
${ }^{21}$ Results for PATENT_I_Sign in Model A4 (Appendix C, Table 6) are not robust to the inclusion of WEALTH_I_SIGN and POWER_I_SIGN when all other controls are excluded. Such a fit obscures the effect of PATENT_I_SIGN as it gives much more exposure to the high level of correlation between these three variables (see Table 2).
} 
indicating that our major results hold across different areas of environmental regulation (Model 1 stratified on Issues is shown in Appendix C, Table 7).

Third, to account for potential correlation of ratifications patterns by treaty rather than country we refitted all our models with a cluster on "treaties". Clustering our observation on treaties, however, does not alter our major result for pooled expertise. In Appendix C, Table 7 we present Model 1 clustered on treaties.

Fourth, we also refitted models from Table 4 including the full set of controls, controlling for regime type with POLITY2 rather than MEANPC. All those estimations confirm the major findings presented in Table 4, and do not alter our results in any substantial way (see Appendix C, Table 7).

Finally, we estimated several models to examine whether an increase in the number of domestic veto players alters the effect of pooled expertise on states' propensity to ratify. Although our theory does not make a directional prediction for domestic constraints, we tested empirically for the interaction between expertise and veto players, measured as the level of constraint on the executive. ${ }^{22}$ However, we did not find a substantively important effect of domestic constraints in either direction.

\section{Conclusion}

We argue that the signing of treaties is more than a political ritual. Our theory predicts that the greater the weight of international opinion signaled by initial signatories, the greater the chance that the treaty will subsequently be ratified. Our theory highlights a non-obvious reason for choosing an international treaty over domestic legislation: international treaties may sway domestic veto players if

\footnotetext{
${ }^{22}$ To measure domestic veto structure, we used the executive constraint variable from the Polity project (XCONST) (Marshall, Gurr and Jaggers, 2014). Second, to specifically reflect environmental concerns, we calculate a score reflecting the position of the median member's party on environmental issues (ENV_LEG) using the Comparative Manifestoes Project information on the emphasis placed on the environment in parties' election manifestoes (Klingemann et al., 2006).
} 
they distrust their own leader. Empirically, we provide evidence that the weight of international opinion does, indeed, increase the chances of subsequent ratification of environmental treaties. Our theory suggests that potential vetoes are swayed by the pooled expertise of signatories. Qualitative case studies would allow us to better understand the precise causal mechanism that underlies our finding. Where vetoes are defined by the constitution as in the case of second chambers cited above, it should be possible to carry out such research by examining debates and reports and by carrying out interviews.

Although our empirical results concern environmental treaties, effects should also operate in other domains, such as international human rights treaties. Even if democratic states can act alone on human rights (Simmons, 2009; 2010), international treaty signature may remove domestic legislative roadblocks and facilitate the treaty route. Thus our analysis complements constructivist accounts of how human rights norms arise (e.g. Risse and Sikkink, 1999). States use the weight of international opinion strategically to persuade domestic veto players about a norm.

Our findings counteract prevalent skepticism regarding the significance of international treaties. Some argue that it is harder to understand why states incur the costs of treaty negotiation when domestic action would suffice or when one state's action would not affect the payoffs of others. For instance, why must established democracies ratify human rights treaties when their independent judiciaries provide credible commitment at the domestic level (Simmons, 2010)? ${ }^{23}$ Other argue that states only sign shallow agreements that do not matter and that are consistent with what they intend to do anyway for domestic reasons (Downs, Rocke and Barsoom, 1996), and the design of treaties may reflect this (Mitchell, 2009; von Stein, 2005). Our model suggests that treaties persuade domestic veto players,

\footnotetext{
${ }^{23}$ Indeed such states are somewhat less prone to ratify than new democracies that have an interest in signaling their commitment, both domestically and internationally Hafner-Burton, Mansfield and Pevehouse, 2015.
} 
1 even if the treaty does not go beyond what leaders would do for purely domestic

2 reasons. Pooling information at the international level and then transferring it to

3 the domestic level by highly visible signals is an important function of international 4 legal processes. 


\section{References}

Abbott, Kenneth and Duncan Snidal. 2000. "Hard and soft law in international governance." International Organization 54(3):421-456.

Andersen, Per K. and Richard D. Gill. 1982. "Cox's regression model for counting processes: A large sample study." Annals of Statistics 10(4):1100-1120.

Axelrod, Robert and Robert O. Keohane. 1985. "Achieving cooperation under anarchy: Strategies and institutions." World Politics 38(1):226-254.

Barrett, Scott. 2003. Environment and Statecraft: The Strategy of Environmental Treaty-Making. Oxford: Oxford University Press.

Beck, Nathaniel, Jonathan N. Katz and Richard Tucker. 1998. "Taking time seriously: Time-series-cross-section analysis with a binary dependent variable." American Journal of Political Science 42(4):1260-1288.

Bendor, Jonathan and Adam Meirowitz. 2004. "Spatial models of delegation." American Political Science Review 98:293-310.

Bernauer, Thomas, Anna Kalbhenn, Vally Koubi and Gabriele Spilker. 2010. "A Comparison of International and Domestic Sources of Global Governance Dynamics." British Journal of Political Science 40:509-538.

Box-Steffensmeier, Janet M. and Bradford S. Jones. 2004. Event History Modeling. A Guide for Social Scientists. New York: Cambridge University Press.

Box-Steffensmeier, Janet M. and Christopher Zorn. 2002. "Duration models for repeated events." Journal of Politics 64(4):1069-1094.

Brown, Joseph M. and Johannes Urpelainen. 2015. "Picking treaties, picking winners. International treaty negotiations and the strategic mobilization of domestic interests." Journal of Conflict Resolution 59(6):1043-1073.

Carter, David B. and Curtis S. Signorino. 2010. "Back to the future: Modeling time dependence in binary data." Political Analysis 18(3):271-292.

Center for International Earth Science Information Network (CIESIN). 2006. "Environmental Treaties and Resource Indicators (ENTRI)." Available at: http: //sedac.ciesin.columbia.edu/entri/.

Central Intelligence Agency (CIA). 2013. "The World Factbook 201314." Washington, DC: CIA. Available at: https://www.cia.gov/library/ publications/the-world-factbook/index.html.

Chapman, Terrence L. 2007. "International security institutions, domestic politics, and institutional legitimacy." Journal of Conflict Resolution 51(1):134-166.

Downs, George W., David M. Rocke and Peter N. Barsoom. 1996. "Is the good news about compliance good news about cooperation?" International Organization 50(3):379-406. 
Elkins, Zachary, Tom Ginsburg and James Melton. 2010. "Comparative Constitutions Project: A Cross-National Historical Dataset of Written Constitutions." Available at: http://comparativeconstitutionsproject.org/.

Espínola-Arredondo, Ana and Félix Muñoz-García. 2011. "Free-riding in international environmental agreements: A signaling approach to non-enforceable treaties." Journal of Theoretical Politics 23(1):111-134.

Falkner, Robert. 2012. Business power, business conflict: A neo-pluralist perspective on international environmental politics. In Handbook of Global Environmental Politics, ed. Peter Dauvergne. Cheltenham: Edward Elgar pp. 319-329.

Fearon, James D. 1997. "Signaling foreign policy interests: Tying hands versus sinking costs." Journal of Conflict Resolution 41(1):68-90.

Feddersen, Timothy J. and Wolfgang Pesendorfer. 1996. "The Swing voter's curse." The American Economic Review 86(3):pp. 408-424.

Fredriksson, Per G. and Noel Gaston. 2000. "Ratification of the 1992 Climate Change Convention: What determines legislative delay?" Public Choice 104(3):345-368.

Freedom House. 2015. "Freedom in the World." Available at: https:// freedomhouse.org/report-types/freedom-world\#.VZ-sMvlsHT8.

Gilligan, Thomas W. and Keith Krehbiel. 1990. "Organization of informative committees by a rational legislature." American Journal of Political Science $34(2): 531-564$.

Hafner-Burton, Emilie M., David G. Victor and Yonatan Lupu. 2012. "Political science research on international law: The state of the field." The American Journal of International Law 106(1):47-97.

Hafner-Burton, Emilie M., Edward D. Mansfield and Jon C.W. Pevehouse. 2015. "Human rights institutions, sovereignty costs and democratization." British Journal of Political Science 45(1):1-27.

Heston, Alan, Robert Summers and Bettina Aten. 2009. "Penn World Table Version 6.3." Center for International Comparisons of Production, Income and Prices, University of Pennsylvania.

Hollyer, James R. and Peter B. Rosendorff. 2012. "Leadership survival, regime type, policy uncertainty and PTA accession." International Studies Quarterly $56(4): 748-764$.

Igoe Walsh, James. 2007. "Do states play signaling games?" Cooperation and Conflict 42(4):441-459.

Institute for Agriculture and Trade Policy. 2005. "The Treaty Database. U.S. Compliance with Global Treaties." Available at: http://www. iatp.org/files/ 451_2_60426.pdf. 
Klein, John P. and Melvin L. Moeschberger. 2003. Survival Analysis. Techniques for Censored and Truncated Data. 2nd ed. New York: Springer Verlag.

Klingemann, Hans-Dieter, Andrea Volkens, Judith Bara, Ian Budge and Michael D. McDonald. 2006. Mapping Policy Preferences II: Estimates for Parties, Electors, and Governments in Eastern Europe, European Union, and OECD 1990-2003. Oxford: Oxford Univeristy Press.

Leinaweaver, Justin. 2011. "The marketing of environmental treaties: Non-Binding signature as information and raising public awareness.".

Lipson, Charles. 1991. "Why are some international agreements informal?" International Organization 45(4):495-538.

Marshall, Monty G., Ted R. Gurr and Keith Jaggers. 2014. "Polity IV Project: Political Regime Characteristics and Transitions, 1800-2013." Available at: http://www. systemicpeace.org/inscrdata.html.

Milner, Helen V. 1997. Interests, Institutions, and Information: Domestic Politics and International Relations. Princeton, N.J.: Princeton University Press.

Mitchell, Ronald B. 2009. The influence of international institutions: Institutional design, compliance, effectiveness, and indigeneity. In Power, interdependence and non-state actors in World Politics: Research frontiers., ed. Helen V. Milner. Princeton: Princeton Univeristy Press pp. 66-83.

Mitchell, Sara McLaughlin and Paul R. Hensel. 2007. "International Institutions and Compliance with Agreements." American Journal of Political Science $51(4): 721-737$.

Mo, Jongryn. 1995. "Domestic institutions and international bargaining: The role of agent veto in two-level games." American Political Science Review 89(4):914924.

Morrow, James D. 2000. "Alliances: Why write them down?" Annual Review of Political Science 3:63-83.

Neumayer, Eric. 2002. "Do Democracies exhibit stronger international environmental commitment? A cross-country analysis." Journal of Peace Research 39(2):139-164.

Perrin, Sophie and Thomas Bernauer. 2010. "International regime formation revisited: Explaining ratification behaviour with respect to long-range transboundary air pollution agreements in Europe." European Union Politics 11(3):405-426.

Putnam, Robert D. 1988. "Diplomacy and domestic politics: The logic of two-level games." International Organization 42(3):427-460.

Risse, Thomas and Kathryn Sikkink. 1999. The socialization of international human rights norms in domestic practices. In The Power of Human Rights: International Norms and Domestic Change, ed. Thomas Risse, Stephen C. Ropp and Kathryn Sikkink. Cambridge: Cambridge University Press pp. 1-38. 
Roberts, J. Timmons, Bradley C. Parks and Alexis A. Vásquez. 2004. "Who ratifies environmental treaties and why? Institutionalism, structuralism and participation by 192 nations in 22 treaties." Global Environmental Politics 4(3):22-64.

Schmidt, Andreas, Ana Ivanova and Mike S. Schäfer. 2013. "Media attention for climate change around the world: A comparative analysis of newspaper coverage in 27 countries." Global Environmental Change 23(5):1233-1248.

Schneider, Christina J. and Johannes Urpelainen. 2013. "Distributional conflict between powerful states and international treaty ratification." International Studies Quarterly 57(1):13-27.

SCImago Research Group. 2015. "SCImago Journal Ranking Indicator." Available at: http://www.scimagojr.com/.

Simmons, Beth A. 2009. Mobilizing for Human Rights. International Law in Domestic Politics. New York: Cambridge University Press.

Simmons, Beth A. 2010. "Treaty compliance and violation." Annual Review of Political Science 13:273-296.

Singer, J. David, Stuart Bremer and John Stuckey. 1972. Capability distribution, uncertainty, and major power war, 1820-1965. In Peace, War, and Numbers, ed. Bruce Russett. Beverly Hills: Sage pp. 19-48.

Slantchev, Branislav L. 2005. "Military coercion in interstate crises." American Political Science Review 99:533-547.

Tableman, Mara and Jong Sung Kim. 2004. Survival Analysis Using S. Analysis of Time-to-Event Data. London: Chapman \& Hall.

Therneau, Terry M. and Patricia M. Grambsch. 2000. Modeling Survival Data: Extending the Cox Model. New York: Springer Verlag.

Vienna Convention on the Law of Treaties. 1969. "1155 U.N.T.S. 331, reprinted in 8 I.L.M. 679 (May 23, 1969).".

von Stein, Jana. 2005. "Do treaties constrain or screen? Selection bias and treaty compliance." American Political Science Review 99(4):611-622.

von Stein, Jana. 2008. "The international law and politics of climate change. Ratification of the United Nations Framework Convention and the Kyoto Protocol." Journal of Conflict Resolution 52(2):243-268.

Vreeland, James R. 2008. "Political institutions and human rights: Why dictatorships enter into the United Nations Convention Against Torture." International Organization 62(1):65-101.

Ward, Hugh. 2006. "International Linkages and Environmental Sustainability: The Effectiveness of the Regime Network." Journal of Peace Research 43(2):149-166.

World Bank. 2015. "World Development Indicators." Available at: http://data. worldbank. org/indicator/NY. GDP. MKTP.CD. 


\section{- A Appendix: A formal model of signing}

2

There are $N$ states. Each country has a legislature $L$ and an executive $E$. The states must decide whether to implement a policy to deal with an environmental or other issue. There is an unobserved state variable $S \in\{0,1\}$ which equals 1 with probability $s$, and 0 otherwise. If $S=1$, then the policy is appropriate. If $S=0$, then the policy is not appropriate, either because the underlying issue is not serious, or because the policy will not deal with it effectively. If the policy is implemented in country $i \in\{1, \ldots, N\}$, then actor $J \in\{E, L\}$ receives $S-c_{J i}$; otherwise $\mathrm{s} /$ he receives 0 . Thus $c_{J i}$ is the relative cost of the policy, with the benefit of the policy normalized to 1 or 0 . Different actors may weigh the costs and benefits of legislative action differently; however, we assume $c_{J_{i}} \in(0,1)$, so that all actors will prefer to legislate if and only if the probability of the policy being appropriate is above some threshold.

\section{Information}

Each executive receives a private signal $S_{i} \in\{0,1\}$ where $S_{i}=S$ with probability $\pi_{i}>1 / 2$. Executives differ in their level of expertise $\pi_{i}$. Legislatures receive no signal. All the parameters $c_{J i}, \pi_{i}$ are common knowledge.

For actor $J$ in country $i$, let

$$
K_{J i} \equiv \log \left(\frac{c_{J i}}{1-c_{J i}}\right)-\log \left(\frac{s}{1-s}\right) .
$$

This is the logged, risk-adjusted "cost-benefit ratio" as $J$ sees things before his prior beliefs, $s$, are updated. Note that $K_{J i}>0$ if and only if $s-c_{J i}<0$, which means that the actor is an ex ante "sceptic" who would not pass legislation in the absence of positive evidence that the policy is appropriate. 
Let $\alpha_{i}$ be executive $i$ 's logged odds of an accurate signal, or "expertise" for short:

$$
\alpha_{i} \equiv \log \left(\frac{\pi_{i}}{1-\pi_{i}}\right)
$$

Since $\pi_{i}>1 / 2, \alpha_{i}$ is positive. Suppose any actor has belief $\mu$ that the policy is appropriate. Then he will wish to pass legislation if

$$
\mu-c_{J i} \geq 0
$$

A little algebra transforms this into

$$
\log \left(\frac{\mu}{1-\mu}\right) \geq \log \left(\frac{c_{J i}}{1-c_{J i}}\right)=K_{J i}+\log \left(\frac{s}{1-s}\right)
$$

By Bayes' rule, for any signal $S_{i}$,

$$
\mu=\operatorname{Prob}\left(S=1 \mid S_{i}=1\right)=\frac{\pi_{i} s}{\pi_{i} s+\left(1-\pi_{i}\right)(1-s)}
$$

and transforming to odds and taking logs:

$$
\log \left(\frac{\mu}{1-\mu}\right)=\alpha_{i}+\log \left(\frac{s}{1-s}\right)
$$

Similarly $\operatorname{Prob}\left(S=1 \mid S_{i}=0\right)=-\alpha_{J i}+\log \left(\frac{s}{1-s}\right)$. Hence an executive will wish to implement the policy, conditional on his own positive signal, if $\alpha_{i} \geq K_{E i}$; and conditional on his own negative signal, if $-\alpha_{i} \geq K_{E i}{ }^{24}$ This additive logic extends to multiple signals: conditional on any number of observed or inferred

\footnotetext{
${ }^{24}$ Signing on a negative signal can only occur if costs are negative. Reputational effects could be modelled in this way.
} 
signals, player $J$ in country $i$ will wish to implement the policy if

$$
\sum_{h ; S_{h}=1} \alpha_{h}-\sum_{h ; S_{h}=0} \alpha_{h} \geq K_{J i}
$$

\section{Adoption of domestic legislation}

To show the signaling advantages of the treaty route over domestic legislation, we first model the introduction of domestic legislation to implement the policy. Recall that the standard advantages of international treaties (e.g. coordinated policy-making across nations) have been assumed away. Nevertheless, comparing domestic legislation to treaty signature shows a new potential advantage: treaty signature allows domestic vetoes to infer many executives' signals on the policy.

We assume that without the publicity afforded by the negotiation process, no state observes the legislative process in any other state. Therefore, individual legislation is modelled as follows: the executive chooses whether to propose the policy as a bill in parliament; if the executive proposes, then the legislature accepts or rejects; if the legislature accepts, legislation is passed.

The executive has three pure strategies: ALWAYS propose legislation, NEVER propose, or CONDITION on her signal i.e. propose iff $S_{E}=1$. We rule out the fourth strategy, proposing if and only if her signal is 0 , as weakly dominated. We also assume that, even if the legislature always rejects, the executive will only propose if he expects legislation to be beneficial. If the executive proposes, the legislature can either accept or reject. We will rule out some uninteresting equilibria with the Intuitive Criterion: if the executive plays NEVER, then out of equilibrium the legislature believes $S_{J}=1$ if after observing a proposal.

Table 5 shows the conditions for each pair of possible strategies to be in equilibrium. (We drop the $i$ subscript temporarily.) If the executive plays CONDITION or NEVER, then the legislature assumes after a proposal that the executive re- 


\begin{tabular}{cccc}
\hline $\begin{array}{c}\text { Legislature } \backslash \\
\text { Executive }\end{array}$ & ALWAYS & CONDITION & NEVER \\
\hline Accept & $K_{E} \leq-\alpha$ & $-\alpha<K_{E} \leq \alpha$ & $\alpha<K_{E}$ \\
& $K_{L} \leq 0$ & $K_{L} \leq \alpha$ & $K_{L} \leq \alpha$ \\
\hline Reject & $K_{E} \leq-\alpha$ & $-\alpha<K_{E} \leq \alpha$ & $\alpha<K_{E}$ \\
& $0<K_{L}$ & $\alpha<K_{L}$ & $\alpha<K_{L}$ \\
\hline
\end{tabular}

Table 5: Single country conditions for different equilibrium strategies.

1 ceived $S_{E}=1 .^{25}$

\section{Ratification of an international treaty}

Just as in the domestic case executives have three undominated pure strategies: ALWAYS sign; CONDITION, i.e. sign conditional on your own positive signal; and NEVER sign. Suppose that a set of $Q$ of executives condition on their signals and only sign if $S_{i}=1$ for $i \in Q$. As before we will assume that executives who never sign are treated by executives, out of equilibrium, as conditioning: call the set of such executives $R$. Executives also benefit from the knowledge of their peers; hence executive $i$ will sign if and only if

$$
\sum_{j \in Q \cup R} \alpha_{j} \pm \alpha_{i} \geq K_{E i}
$$

Therefore, in an equilibrium where the treaty is tabled, recalling that this 4 requires unanimity, each executive's best strategy is: ${ }^{26}$

\footnotetext{
${ }^{25}$ If the executive plays CONDITION then this belief is uniquely specified by Weak Perfect Bayesian equilibrium. If the executive plays NEVER, then this belief can be justified by the Intuitive Criterion: the out-of-equilibrium proposal would give a highest expected benefit to an executive who had received a positive signal, so this is what the legislature believes.

${ }^{26}$ If the treaty is tabled, along the equilibrium path the set $R$ is empty and all members of $Q$ sign, so they all received positive signals. In the main text we ignore $R$, since if it is non-empty no treaty can be signed.
} 


$$
\begin{array}{ll}
\text { ALWAYS } & \text { if } \sum_{j \in Q \cup R, j \neq i} \alpha_{j}-\alpha_{i} \geq K_{E i}, \\
\text { CONDITION } & \text { if } \sum_{j \in Q \cup R, j \neq i} \alpha_{j}-\alpha_{i}<K_{E i} \leq \sum_{j \in Q \cup R, j \neq i} \alpha_{j}+\alpha_{i}, \\
\text { NEVER } & \text { if } \sum_{j \in Q \cup R, j \neq i} \alpha_{j}+\alpha_{i}<K_{E i} .
\end{array}
$$

The legislature in country $i$ will then ratify in such an equilibrium if and only if

$$
\sum_{j \in Q \cup R} \alpha_{j} \geq K_{L i}
$$

1

An equilibrium requires sets $Q$ and $R$ satisfying the appropriate condition above for each individual in each set. There may be multiple equilibria in which a treaty is tabled. For instance, suppose $N=3$ with $\alpha_{1}=\alpha_{2}=\alpha_{3}=\alpha$ and $K_{E 1}=K_{E 2}=K_{E 3}=K$. If $0<K<\alpha$, then there are three equilibria in which two executives condition on their signal, and the other always signs. This is a typical example of the "swing voter's curse" (Feddersen and Pesendorfer, 1996), where conditional on the other two executives signing, the third executive wishes to sign irrespective of his or her own signal. We examine the effect of the swing voter's curse below, by simulating equilibria.

To examine the effect of an increase in the number of veto players in country $i$, write the cost of the most skeptical veto player when there are fewer veto players as $K_{L i}$, and the cost when there are more veto players as $K_{L i}^{\prime}$. Of course $K_{L i} \leq K_{L i}^{\prime}$; assume the inequality is strict. Consider, in each of the two cases, the effect of an increase in summed expertise $\left(\sum_{Q} \alpha_{j}\right)$, from a value of $A$ to $A^{\prime}$. There are the following possibilities:

(a) $K_{L i}^{\prime}<A$. In this case the most skeptical veto player in country $i$ can be 
1 convinced even by the lower level of expertise; more expertise has no further 2 effect, irrespective of the number of veto players.

${ }_{3}$ (b) $K_{L i}<A<K_{L i}^{\prime}<A^{\prime}$. In this case, as the number of veto players goes up, 4 the effect of higher expertise is increased. With fewer veto players, country ${ }_{5} \quad i$ is always persuaded irrespective of the level of expertise. With more veto $6 \quad$ players, only a stronger signal of expertise will persuade the most skeptical $7 \quad$ veto player.

8 (c) $A<K_{L i}<K_{L i}^{\prime}<A^{\prime}$. Here again there is no marginal effect of an increase in $9 \quad$ veto players, since either way country $i$ is only persuadable by the higher level of summed expertise.

(d) $A<K_{L i}<A^{\prime}<K_{L i}^{\prime}$. Now the marginal effect of an increase in veto players is to reduce the effect of the increase in expertise. With fewer veto players, country $i$ only ratifies in response to a strong signal. With more veto players it never ratifies.

(e) $K_{L i}<A<A^{\prime}<K_{L i}^{\prime}$.

(f) $A^{\prime}<K_{L i}$. In both these cases there is again no marginal effect, since country $i$ is either persuaded at both levels of expertise or at neither. 


\section{B Appendix: Simulations of equilibria}

In our model, some executives condition on their own signal of policy appropriateness, while others do not and effectively free-ride on the knowledge of their peers. Legislatures are only persuaded by those executives who are conditioning. However, in our empirics we only observe which states sign a treaty, and not whether they were conditioning (or more broadly, how much information is conveyed by their signature).

To check whether this makes a difference, we simulated equilibria for different numbers of states and random draws of $\alpha$ and $\kappa$ terms. We discarded cases where there was no pure strategy equilibrium. We also discarded cases where the only pure strategy equilibrium had one or more states never signing, since these equilibria are not observable in our dataset. We ran simulations until we had 100 valid draws, for 3, 5, 8 and 15 states. We then correlated the total sum of $\alpha$ terms of all signers, with the total sum of $\alpha$ terms of signers who were conditioning. Results are shown below. The correlation was strong and significant for all numbers of states, though the correlation is smaller as $n$ increases. Thus, the total knowledge of signing states appears to be a good proxy for the real causal variable in our theory, the total knowledge of signers who are conditioning.

$\alpha$ values were drawn independently for each country from the uniform distribution on $[0,3] . \kappa$ values were drawn independently from the standard log normal distribution. Code is available on request.

\begin{tabular}{ccc}
\hline Number of countries & Correlation (95\% conf. int.) & $p$-value \\
\hline 3 & $.79(0.70,0.85)$ & $<0.001$ \\
5 & $.75(0.64,0.82)$ & $<0.001$ \\
8 & $.49(0.32,0.62)$ & $<0.001$ \\
15 & $.27(0.08,0.45)$ & 0.005 \\
\hline
\end{tabular}


C Appendix: Further empirical tests

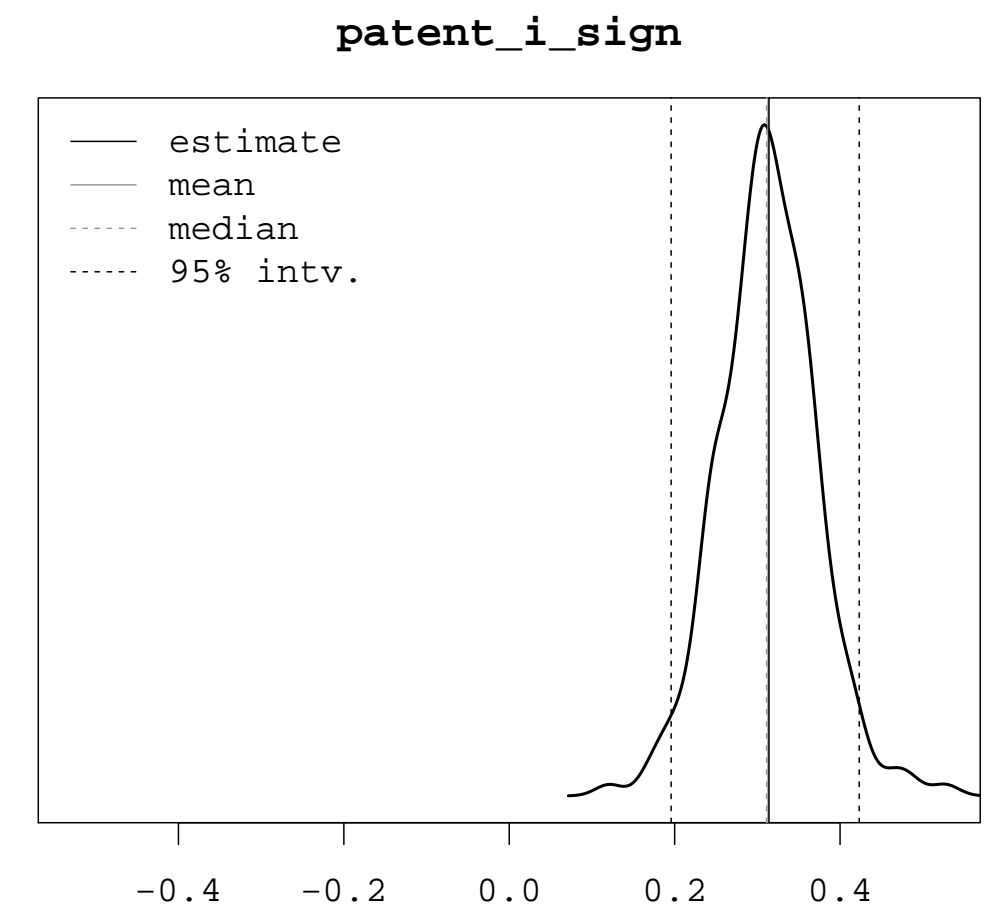

Figure 1: Posterior distributions of parameter estimates for coefficient values obtained by bootstrap resampling for Model 1 from Table 4.

Note: The figure reports estimates of coefficient values, not hazard ratios. 


\begin{tabular}{|c|c|c|c|c|}
\hline & $\begin{array}{c}\text { Model A1 } \\
\exp (\text { coef }) \\
(p)\end{array}$ & $\begin{array}{c}\text { Model A2 } \\
\exp (\text { coef }) \\
(p)\end{array}$ & $\begin{array}{c}\text { Model A3 } \\
\exp (\text { coef }) \\
(p)\end{array}$ & $\begin{array}{c}\text { Model A4 } \\
\exp (\text { coef }) \\
(p)\end{array}$ \\
\hline \multicolumn{5}{|l|}{ Pooled expertise } \\
\hline PATENT_I_SIGN & $\begin{array}{c}1.341 \\
\left(0.000^{* * *}\right)\end{array}$ & & & $\begin{array}{c}0.998 \\
(0.943)\end{array}$ \\
\hline EXPERIENCE_I_SIGN & & $\begin{array}{c}1.152 \\
(0.000 * * *)\end{array}$ & & \\
\hline MARINE_I_SIGN & & & $\begin{array}{c}1.093 \\
\left(0.000^{* * *}\right) \\
\end{array}$ & \\
\hline \multicolumn{5}{|l|}{ Controls } \\
\hline FIRST_SIGN & $\begin{array}{c}8.119 \\
\left(0.000^{* * *}\right)\end{array}$ & $\begin{array}{c}10.889 \\
\left(0.000^{* * *}\right)\end{array}$ & $\begin{array}{c}10.445 \\
\left(0.000^{* * *}\right)\end{array}$ & $\begin{array}{c}5.788 \\
\left(0.000^{* * *}\right)\end{array}$ \\
\hline WEALTH_I_SIGN & & & & $\begin{array}{c}1.360 \\
\left(0.000^{* * *}\right)\end{array}$ \\
\hline POWER_I_SIGN & & & & $\begin{array}{c}1.025 \\
(0.500)\end{array}$ \\
\hline R_COAST_LAND & & & $\begin{array}{c}1.093 \\
\left(0.01^{* *}\right) \\
\end{array}$ & \\
\hline LRT & 5928 & 6052 & 1485 & 6285 \\
\hline$(p)$ & $(0)$ & $(0)$ & $(0)$ & $(0)$ \\
\hline Wald test & 4210 & 3773 & 1533 & 5830 \\
\hline$(p)$ & $(0)$ & $(0)$ & $(0)$ & $(0)$ \\
\hline Robust (score) logrank test & 152.3 & 139.5 & 121 & 158.5 \\
\hline$(p)$ & $(0)$ & $(0)$ & $(0)$ & $(0)$ \\
\hline No. Observations & 266642 & 342668 & 157595 & 266642 \\
\hline No. Events & 3870 & 4306 & 1150 & 3870 \\
\hline No. States & 190 & 190 & 185 & 190 \\
\hline Period & $1961-2000$ & $1952-2000$ & 1959-2000 & $1961-2000$ \\
\hline
\end{tabular}

Table 6: Cox proportional hazards regression models for treaty ratification.

Notes: Each cell entry $[\exp (\operatorname{coef})]$ is the exponential of the coefficient which is the hazard ratio (HR). The likelihood ratio test assumes independence of observations within a cluster (country); the Wald and robust score tests do not. ${ }^{* * *} p|z|=<.001,{ }^{* *} p|z|=<.01,{ }^{*} p|z|=<.05$. 


\begin{tabular}{|c|c|c|c|c|}
\hline & $\begin{array}{c}\text { Model A5 } \\
\text { (strata: ISSUES) } \\
\exp (\text { coef }) \\
(p)\end{array}$ & $\begin{array}{c}\text { Model A6 } \\
\text { (cluster: treaties) } \\
\exp (\text { coef }) \\
(p)\end{array}$ & $\begin{array}{c}\text { Model A7 } \\
\exp (\text { coef }) \\
(p)\end{array}$ & $\begin{array}{c}\text { Model A8 } \\
\exp (\text { coef }) \\
(p)\end{array}$ \\
\hline \multicolumn{5}{|l|}{ Pooled expertise } \\
\hline PATENT_I_SIGN & $\begin{array}{c}1.363 \\
\left(0.000^{* * *}\right)\end{array}$ & $\begin{array}{c}1.369 \\
(0.000 * * *)\end{array}$ & $\begin{array}{c}1.354 \\
(0.000 * * *)\end{array}$ & $\begin{array}{c}1.634 \\
\left(0.000^{* * *}\right)\end{array}$ \\
\hline \multicolumn{5}{|l|}{ Controls } \\
\hline FIRST_SIGN & $\begin{array}{c}4.195 \\
\left(0.000^{* * *}\right)\end{array}$ & $\begin{array}{c}4.659 \\
\left(0.000^{* * *}\right)\end{array}$ & $\begin{array}{c}5.205 \\
\left(0.000^{* * *}\right)\end{array}$ & \\
\hline IO_MEMBERSHIP & $\begin{array}{c}1.006 \\
\left(0.036^{*}\right)\end{array}$ & $\begin{array}{c}1.005 \\
(0.051)\end{array}$ & $\begin{array}{c}1.005 \\
(0.120)\end{array}$ & $\begin{array}{c}1.012 \\
\left(0.000^{* * *}\right)\end{array}$ \\
\hline THRESHOLD & $\begin{array}{c}1.006 \\
(0.000 * * *)\end{array}$ & $\begin{array}{c}1.005 \\
(0.123)\end{array}$ & $\begin{array}{c}1.004 \\
\left(0.013^{*}\right)\end{array}$ & $\begin{array}{c}1.006 \\
\left(0.000^{* * *}\right)\end{array}$ \\
\hline LAGPERCREGION & $\begin{array}{c}1.020 \\
(0.000 * * *)\end{array}$ & $\begin{array}{c}1.019 \\
\left(0.000^{* * *}\right)\end{array}$ & $\begin{array}{c}1.019 \\
\left(0.000^{* * *}\right)\end{array}$ & $\begin{array}{c}1.023 \\
\left(0.000^{* * *}\right)\end{array}$ \\
\hline OPEN & $\begin{array}{c}0.966 \\
(0.460)\end{array}$ & $\begin{array}{c}0.963 \\
(0.241)\end{array}$ & $\begin{array}{c}0.939 \\
(0.102)\end{array}$ & $\begin{array}{c}0.967 \\
(0.373)\end{array}$ \\
\hline RGDPL & $\begin{array}{c}1.101 \\
(0.432)\end{array}$ & $\begin{array}{c}1.158 \\
(0.093)\end{array}$ & $\begin{array}{c}1.376 \\
\left(0.047^{*}\right)\end{array}$ & $\begin{array}{c}1.067 \\
(0.544)\end{array}$ \\
\hline RGDPLSQ & $\begin{array}{c}0.960 \\
(0.698)\end{array}$ & $\begin{array}{c}0.922 \\
(0.316)\end{array}$ & $\begin{array}{c}0.815 \\
(0.222)\end{array}$ & $\begin{array}{c}0.989 \\
(0.899)\end{array}$ \\
\hline LNSO2PC & $\begin{array}{c}1.095 \\
\left(0.000^{* * *}\right)\end{array}$ & $\begin{array}{c}1.095 \\
\left(0.000^{* * *}\right)\end{array}$ & $\begin{array}{c}1.068 \\
\left(0.014^{*}\right)\end{array}$ & $\begin{array}{c}1.099 \\
\left(0.000^{* * *}\right)\end{array}$ \\
\hline MEANPC & $\begin{array}{c}1.120 \\
\left(0.000^{* * *}\right)\end{array}$ & $\begin{array}{c}1.116 \\
\left(0.000^{* * *}\right)\end{array}$ & & $\begin{array}{c}1.133 \\
\left(0.000^{* * *}\right)\end{array}$ \\
\hline POLITY2 & & & $\begin{array}{c}1.021 \\
\left(0.002^{* *}\right)\end{array}$ & \\
\hline GDPL & $\begin{array}{c}0.956 \\
\left(0.028^{*}\right) \\
\end{array}$ & $\begin{array}{c}0.959 \\
\left(0.027^{*}\right)\end{array}$ & $\begin{array}{c}0.960 \\
\left(0.023^{*}\right) \\
\end{array}$ & $\begin{array}{c}0.954 \\
\left(0.009^{* *}\right)\end{array}$ \\
\hline LRT & 5071 & 6002 & 6006 & 4813 \\
\hline$(p)$ & $(0)$ & $(0)$ & $(0)$ & $(0)$ \\
\hline Wald test & $\begin{array}{c}3213 \\
(0)\end{array}$ & $\begin{array}{c}994.3 \\
(0)\end{array}$ & $\begin{array}{c}4297 \\
(0)\end{array}$ & $\begin{array}{c}2948 \\
(0)\end{array}$ \\
\hline $\begin{array}{l}\text { Robust (score) logrank test } \\
(p)\end{array}$ & $\begin{array}{c}140.3 \\
(0)\end{array}$ & $\begin{array}{l}55.74 \\
(0)\end{array}$ & $\begin{array}{c}131.9 \\
(0)\end{array}$ & $\begin{array}{l}141.1 \\
(0)\end{array}$ \\
\hline No. Observations & 205384 & 205384 & 199698 & 205384 \\
\hline No. Events & 3002 & 3002 & 3036 & 3002 \\
\hline No. States & 157 & & 149 & 157 \\
\hline No. Treaties & & 112 & & \\
\hline Period & $1972-2000$ & $1972-2000$ & $1965-2000$ & $1972-2000$ \\
\hline
\end{tabular}

Table 7: Cox proportional hazards regression models for treaty ratification.

Notes: Each cell entry $[\exp ($ coef $)]$ is the exponential of the coefficient which is the hazard ratio (HR). The likelihood ratio test assumes independence of observations within a cluster (country); the Wald and robust score tests do not. ${ }^{* * *} p|z|=<.001,{ }^{* *} p|z|=<.01,{ }^{*} p|z|=<.05$. 